\title{
On-farm Verification of Potassium Fertilization for Major Cereal Crops under Balanced Fertilizers in North Shew Zone of Amhara Region, Ethiopia
}

Kenzemed Kassie ( $\square$ kenzemedk@gmail.com )

Debre Birhan Agricultural Research Center, P.O.Box 112, Debre Birhan, Ethiopia

Beza Shewangizaw

Debre Birhan Agricultural Research Center

Getachew Lema

Debre Birhan Agricultural Research Center

Lisanu Getaneh

Debre Birhan Agricultural Research Center

Genet Taye

Debre Birhan Agricultural Research Center

Abiro Tigabie

Debre Birhan Agricultural Research Center

\section{Research Article}

Keywords: sorghum, food barley, bread wheat, potassium chloride

Posted Date: November 12th, 2019

DOI: https://doi.org/10.21203/rs.2.16920/v1

License: (c) (1) This work is licensed under a Creative Commons Attribution 4.0 International License.

Read Full License 


\section{Abstract}

The present study was conducted to investigate the response of major cereal crops to application of potassium with balanced fertilizers as well as to validate newly released soil fertility map of Amhara Region. A field experiment was carried out with different districts of North Shewa of Amhara region: Kewet (Sorghum), Basona warana (Food Barley) Moretena jiru and Mojana wedera (Bread wheat. A randomized complete block design was used, with three replications. The treatments were consisted of NPS, NPS+K, NPSBZn, and NPSBZn+K. The required amount of nitrogen and phosphorus were adjusted to crop and site specific recommendation. The rate of $\mathrm{K}$ was $150 \mathrm{~kg} \mathrm{ha}^{-1} \mathrm{~K}_{2} \mathrm{O}$ and applied as a straight fertilizer at planting in the form of potassium chloride $(\mathrm{KCl})$. The highest grain yield of sorghum (4301.9 $\mathrm{kg} \mathrm{ha}^{-1}$ ) was recorded under the treatment of NPSBZ $\mathrm{n}$ and followed by NPS fertilizer application respectively, while lower grain yields ( 3017.7 and $3186.9 \mathrm{~kg} \mathrm{ha}^{-1}$ ) were recorded under the treatments of NPSBZn and NPS with potassium fertilizer application. Even though statically insignificance both NPS and NPSBZn, application of NPSBZn had gave $5.3 \%$ of sorghum grain yield advantage as compared to sole NPS and $\mathrm{N}$ fertilizer application. The highest grain yield of barley (4411 kg ha-1) also was recorded under the treatment of NPS and followed by NPS+K respectively, while lower grain yield $\left(3960.6 \mathrm{~kg} \mathrm{ha}^{-1}\right)$ was recorded under the treatments of NPSBZn. Grain yield of bread also showed similar trend as grain yield of food barley at Moretena jiru and Mojana wedera districts. Generally the results of this experiment did not showed agronomical viable options due to utilization of potassium with recommended NP nutrient sources and micronutrients. The soil was deficient in organic matter, total nitrogen, and available phosphorus and adequate in available potassium. Thus it can be concluded that potassium is not a yield limiting nutrient but soil nitrogen and phosphorus management need especial attention.

\section{Introduction}

Potassium is the third most important macronutrient required for plant growth, after nitrogen and phosphorus, and is one of the principle plant nutrients enhancing crop yield production and quality determination. Potassium is involved in many physiological processes, its impact on water relations, photosynthesis, assimilate transport, and enzyme activation can have direct consequences on crop productivity (Pettigrew, 2008) by regulating the opening and closing of stomata and therefore regulating moisture loss from the plant.

Potassium requirement by plant varies from plant to plant and specie to species. For instance, wheat requires for optimal growth and development while utilization of adequate potassium results in greater quality of the whole plant due to improved photosynthetic efficiency, increased resistance to some diseases, greater water use efficiency, and helps to maintain a normal balance between carbohydrates and proteins. Sufficient $\mathrm{K}$ also contributes stronger straw and assists grain filling in wheat (Agri-News, 2012). Similarly, research findings had shown that application of $50 \mathrm{~kg} \mathrm{~K}_{2} \mathrm{SO}_{4} \mathrm{ha}^{-1}$, wheat grain yield increased by 400,850 and $1100 \mathrm{~kg} \mathrm{ha}^{-1}$ following wheat, tef and legume precursors, respectively (Abiye et al., 2004). 
According to the reviews of Zinabu (2016), many highland soils of Ethiopia are facing the Paradoxical $\mathrm{K}$ status and crop response to $\mathrm{K}$ fertilization. In addition to this newly developed soil fertility map of Amhara region recommended by ATA (2016) recommend that 94 percent of cultivated lands need a straight potassium fertilizer like urea. So that the current experiment was executed to verify the response of major cereal crops to potassium fertilizer with balanced fertilizers in relation to potassium crop response.

\section{Materials And Methods}

\section{Description of Study Area}

Field trials was carried out with 19 sites in Moretena jiru and Mojana wedera (Bread wheat), Basona warana (Food Barley) and Kewet (Sorghum) districts to study the response of these major cereals to application of $\mathrm{K}$ with balanced fertilizers and validate newly released soil fertility map of Amhara Region respectively. The trial was conducted at these districts during the main cropping season (2017 18). Geographically, the experimental sites were located at a range of $09^{\circ} 9^{\prime}$ to $10^{\circ} 03^{\prime} \mathrm{N}$ and $40^{\circ} 02^{\prime}$ to $3809^{\prime} \mathrm{E}$ in Kewet, $09^{0} 36^{\prime}$ to $09^{0} 48^{\prime} \mathrm{N}$ and $39^{\circ} 39^{\prime}$ to $39^{\circ} 50^{\prime} \mathrm{E}$ in Basona warana, $09^{\circ} 91^{\prime}$ to $09^{\circ} 94^{\prime} \mathrm{N}$ and $36^{\circ} 61^{\prime}$ to $39^{0} 67^{\prime} \mathrm{E}$ in Moretena jiru, and $09^{0} 91^{\prime}$ to $09^{\circ} 94^{\prime} \mathrm{N}$ and $36^{\circ} 61^{\prime}$ to $39^{\circ} 67^{\prime} \mathrm{E}$ in Mojana wedera with a mean altitude of $1252-1372 \mathrm{~m}, 2650-2868 \mathrm{~m}, 2605-2666$ and $2678-2935 \mathrm{~m}$ masl respectively.

Figure 1. Map of the study area

Long term climate of the study areas are characterized by a unimodal rainfall pattern and receive an average annual rainfall of $760.2 \mathrm{~mm}, 934.1 \mathrm{~mm}, 910.6 \mathrm{~mm}$ and $928 \mathrm{~mm}$. The long term annual mean rainfall, minimum and maximum air temperatures are presented in figure and Table 1. Vertisols are the dominant soil type. The major cereals widely grown in the main season in the study areas include sorghum, tef, wheat and barley.

Figure: 1 Long term and 2017 mean monthly rainfall distribution of the study area.

-able1: Mean annual minimum and maximum temperature the study area.

\begin{tabular}{lllcccc}
\hline Period & Parameters & Kewet & Basona warana & Moretena jiru & Mojana \\
\cline { 6 - 7 } & & & & & Wedera \\
\cline { 6 - 7 } Long Term & Mean Precipt (mm) & 760.2 & 931.1 & 910.6 & 928.6 \\
2017 & Mean Precipt (mm) & 860.0 & 981.0 & 921.2 & - \\
Long Term & Mean Min Temp & 14.54 & 6.54 & 11.86 & 11.18 \\
2017 & Mean Min Temp (OC) & 16.30 & 6.87 & 9.53 & - \\
Long Term & Mean Max Temp & 29.72 & 19.82 & 25.54 & 24.67 \\
2017 & Mean Max Temp (OC) & 29.20 & 20.4 & 21.67 & - \\
\hline
\end{tabular}

The treatments were constituted by NPS, NPS+K, NPSBZn, and NPSBZn+K with N and P adjusted to the recommended NP using urea and NPS respectively (Table 2). $\mathrm{K}$ was applied as a straight fertilizer at 
planting at the rate of $\mathrm{K}$ was $150 \mathrm{~kg} \mathrm{ha}^{-1} \mathrm{~K}_{2} \mathrm{O}$. These treatments were distributed in randomized complete block design with three replications. For all sites, the experimental plots area was 5 by $5 \mathrm{~m}$ (sorghum and Food barley) and 4.8 by $5 \mathrm{~m}$ (bread wheat). The distance between plots was $50 \mathrm{~cm}$ and between blocks was $1 \mathrm{~m}$ apart. The seeds were sown in rows of $75 \mathrm{~cm}$ at the spacing of $20 \mathrm{~cm}$ between seeds for sorghum, and for wheat and barley $20 \mathrm{~cm}$ between rows. Among the total number of rows the middle rows were used to evaluate the study variables. Recommended varieties of sorghum (Gerana-1), bread wheat (Menze) and food barley (HB1307) was used as test crops. The seed was treated with Apron star to protect head smut ahead of planting. Land was prepared using local maresha and plots were arranged as raised beds (Broad bed furrow) for wheat and barley were sown on flat land with furrow within $3 \mathrm{~m}$ interval for excess water drainage.

־able 2: Treatment details

\begin{tabular}{|c|c|c|c|c|}
\hline$a t$ & Wheat & Barley & & rghum \\
\hline & $\mathrm{N} \mathrm{P}_{2} \mathrm{O}_{5} \mathrm{~K}$ & $\mathrm{P}_{2} \mathrm{O}_{5} \mathrm{~K}_{2} \mathrm{O}$ & & ${ }_{2} \mathrm{O}_{5} \mathrm{~K}_{2} \mathrm{O}$ \\
\hline & 16710 & 46 & 412 & $\begin{array}{ll}46 & 0\end{array}$ \\
\hline & 16 & 150 & 41 & $46 \quad 150$ \\
\hline & $167104 \quad 0 \quad 64$ & 46 & 41 & $46 \quad 0$ \\
\hline 1. $\mathrm{NF}$ & 16710415064 & 46 & 41 & 46150 \\
\hline
\end{tabular}

Before starting the experiment, initial composite soil samples and after harvesting from each experimental treatment were collected from the experimental plots ( $\mathrm{pH}, \mathrm{Av} . \mathrm{P}, \mathrm{OC}, \mathrm{TN}$, exchangeable $\mathrm{K}$ and texture analysis). Soil pH was measured with a glass electrode; samples were diluted in water (the ratio of soil to water was 1:2.5). Total nitrogen was determined using the micro Kjeldahl procedure as described by Bremmer and Mulvaney (1982). Soil organic carbon was determined using the Wet Oxidation Method of Walkley and Black described by Nelson and Sommers (1982). Available phosphorus was determined following Olson and exchangeable potassium was determined with ammonium phosphate following the procedure described by Olson (1954).

\section{Data Analysis}

Results were statistically processed by SAS software (SAS, 2002) for analysis of variance, differences among treatments were detected by least significant difference test (LSD) $(p<0.05)$.

\section{Result And Discussion}

\section{Selected physical and chemical soil properties}

The result of selected physic-chemical analysis results of experimental soil (Table 3 ) before planting revealed that the textural class of the surface soil $(0-20 \mathrm{~cm})$ was mostly clay except two sites of Basona warana district are clay loam (USDA, 1987). The mean pH values were 8.44, 6.03, 6.54 and 7.33 for Kewet, Basona warana, Moretena jiru and Mojana wedera districts respectively which are categorized as strongly alkaline, slightly acidic and neutral (Tekalegn 1991). Mean Soil organic carbon content and total 
nitrogen of the soils were also $1.61 \%$ and $0.14 \%$ (Kewet), $1.25 \%$ and $0.17 \%$ (Basona warana), $0.49 \%$ and $0.12 \%$ (Moretena jiru), and $0.38 \%$ and $0.12 \%$ (Mojana wedera) which are generally low $(0.5-1.5 \%$ ) and medium (1.5-3.0\%), according to Landon (1991).

The initial mean soil test values of exchangeable potassium (K) on Kewet, Basona warana, Moretena jiru and Mojana wedera testing sites were 2.41, 0.60, 0.57 and $0.77 \mathrm{cmolc}^{\mathrm{kg}}{ }^{-1}$ respectively (Table 3). According to the rating of Landon (1991), all results of exchangeable $\mathrm{K}$ fell within the range of $0.3-0.6$

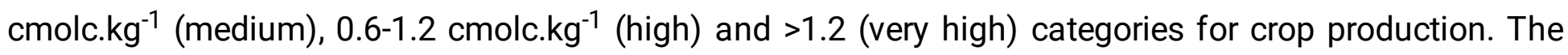
status of available phosphorus for testing sites categorized low to very low status (Landon 1991). Generally from the soil nutrient status result soils of the study areas management of soil organic matter and application of adequate amount of nitrogen and phosphorus containing external fertilizer sources application is indispensable.

Table: 3 Selected physical and chemical properties of the experimental soils of districts, 201718

\begin{tabular}{llccccccccc}
\hline District & Sites kebele & $\mathrm{pH}$ & $\mathrm{OC}$ & $\mathrm{TN}$ & Exch.K & Av.P & Clay & Silt & Sand & Tex. \\
& & $(1: 2.5)$ & $(\%)$ & $(\%)$ & $(\mathrm{Cmol} \mathrm{kg})$ & $(\mathrm{Ppm})$ & $\%$ & $\%$ & $\%$ & Class \\
\hline Kewet & Charie & 8.02 & 1.47 & 0.13 & 1.39 & 5.71 & 50 & 38 & 12 & $\mathrm{C}$ \\
& Zuti & 8.53 & 1.68 & - & 2.35 & - & - & - & - & - \\
\hline & Abayater & 8.77 & 1.66 & 0.13 & 3.20 & 0.39 & 72 & 20 & 8 & $\mathrm{C}$ \\
\hline Sefeberet & 8.45 & 1.64 & 0.16 & 2.69 & 2.58 & 72 & 16 & 12 & $\mathrm{C}$ \\
\hline Mean & & 8.44 & 1.61 & 0.14 & 2.41 & 2.89 & 64.7 & 24.7 & 10.7 & \\
\hline Basona warana & Atakilt & 5.95 & 1.25 & 0.16 & 0.70 & 3.19 & 50 & 24 & 26 & $\mathrm{C}$ \\
& Andit Tid & 6.32 & 1.34 & 0.17 & 0.64 & 2.02 & 38 & 40 & 22 & $\mathrm{CL}$ \\
\hline & Mush-dere & 6.13 & 0.75 & 0.20 & 0.52 & 8.78 & 34 & 42 & 24 & $\mathrm{CL}$ \\
\hline Mean & Mush-yeh & 5.70 & 1.67 & 0.16 & 0.52 & 0.95 & 52 & 34 & 14 & $\mathrm{C}$ \\
\hline Moretena jiru & Mangudo & 6.03 & 1.25 & 0.17 & 0.60 & 3.74 & 43.5 & 35.0 & 21.5 & \\
\hline & Burtilk & 6.40 & 0.54 & 0.14 & 0.60 & 5.15 & 70 & 18 & 12 & $\mathrm{C}$ \\
& Gerba & 6.65 & 0.55 & 0.12 & 0.52 & 12.66 & 78 & 12 & 10 & $\mathrm{C}$ \\
\hline Mean & Bolo & 6.21 & 0.54 & 0.11 & 0.52 & 8.79 & 72 & 16 & 12 & $\mathrm{C}$ \\
\hline Mojana wedera & Begochgat & 6.54 & 0.49 & 0.12 & 0.57 & 9.66 & 73.5 & 16.5 & 10.0 & \\
\hline & Filagenet & 6.62 & 0.47 & 0.16 & 0.70 & 1.57 & 72 & 18 & 10 & $\mathrm{C}$ \\
& Feres & 7.77 & 0.39 & 0.16 & 0.90 & 0.28 & 68 & 22 & 10 & $\mathrm{C}$ \\
\hline & megalebiya & & & & 0.72 & 4.37 & 68 & 20 & 12 & $\mathrm{C}$ \\
& Birka & 7.71 & 0.24 & 0.08 & 0.87 & 0.22 & 76 & 18 & 6 & $\mathrm{C}$ \\
\hline & Sasit & 7.20 & 0.42 & 0.10 & 0.58 & 5.66 & 68 & 26 & 6 & $\mathrm{C}$ \\
\hline Mean & & 7.33 & 0.38 & 0.12 & 0.77 & 2.63 & 70.0 & 21.5 & 8.5 & \\
\hline
\end{tabular}




\section{Effect of Potassium fertilizer under balanced fertilization on Grain Yield of major cereals}

\section{Sorghum}

The mean grain yield of sorghum in terms of kilogram per hectare with application of potassium reduced from $4085.6 \mathrm{~kg} \mathrm{ha}^{-1}$ (NPS and Nitrogen fertilizer) to $3186.6 \mathrm{~kg} \mathrm{ha}^{-1}$ (NPS+K with Nitrogen fertilizer) respectively, also in similar manner yield of sorghum reduced from application of recommended NPS, Nitrogen and with and without potassium and micronutrient fertilizer were from 4301.9 to $3017.7 \mathrm{~kg} \mathrm{ha}^{-}$ ${ }^{1}$ were shown in table 2.

The highest yield was recorded under the treatment of NPSBZn and followed by NPS fertilizer application respectively, while lower grain yields were recorded under the treatments of NPSBZn and NPS with potassium fertilizer application. Even though statically insignificance application of NPSBZn had gave $5.3 \%$ of yield advantage as compared to sole NPS fertilizer application. The possible causes of yield reduction of sorghum under application of potassium with recommended NPS, Nitrogen and micro nutrient where potassium chloride fertilizer had a negative effect that reduce germination and emergence due to high osmotic pressure which have a high salt index when seed-placed with $\mathrm{KCl}$ at time of planting (Gelderman, 2007). In addition to this the potassium status of the study sites hade optimal level of exchangeable potassium as indicated in table 1 of laboratory soil analysis result.

Table: 3 Mean responses of Sorghum Grain and Stoke Yield for application of Potassium fertilizer under balanced fertilization at Kewet District, 201718

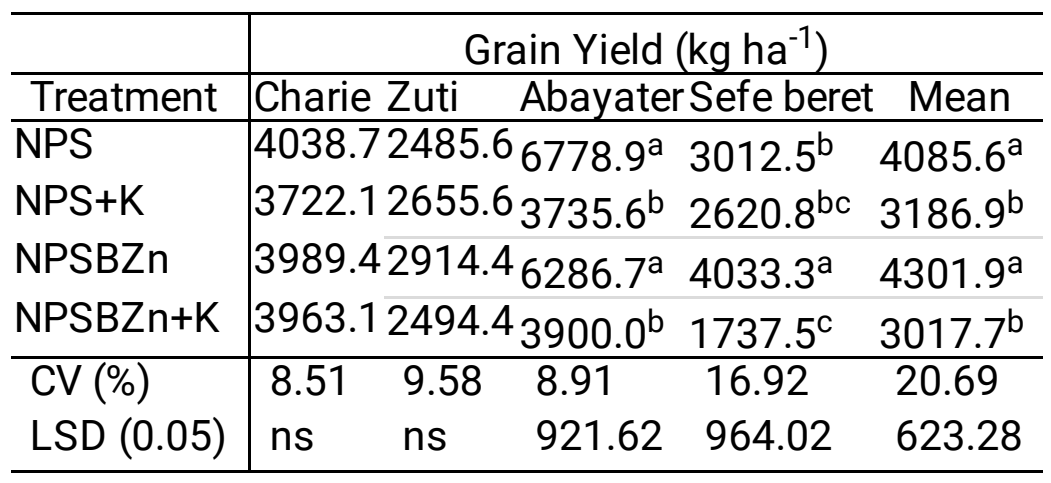

\section{Food barley}

Even though, the production potentials of the study sites were different, there was no significant difference among treatments for overall mean yield parameters of food barley with application of potassium fertilizer with recommended NPS, Nitrogen and micronutrient fertilizers at all sites of Basona warana district presented on Table 4. 
The highest grain yield of barley $\left(4410.2 \mathrm{~kg} \mathrm{ha}^{-1}\right)$ was recorded under the treatment of NPS and followed by NPS with potassium fertilizer application respectively, while lower grain yield (3960.6 kg ha-1) was recorded under the treatments of NPSBZn. Even though statically insignificance both NPS and NPSBZn, application of sole NPS had gave $11.4 \%$ of yield advantage as compared to NPSBZn fertilizer application. In addition, the result revealed that with and without potassium fertilizer application of micronutrient (B and Zn) with recommended NPS and Urea fertilizers had no brought additional yield advantage.

Table 4. Mean response of food barley grain yield for application of Potassium fertilizer under balanced fertilization at Basona warana District, 201718

\begin{tabular}{l|llllll}
\hline Treatment & Faji & \multicolumn{5}{|c}{ Atakilt Andit Tid Mush-Dere Mush-Yeh Mean } \\
\hline NPS & 2660.6 & 1906.05888 .5 & 5837.2 & 6678.2 & 4410.2 \\
NPS + K & 2650.3 & 2202.55915 .0 & 5934.8 & 6704.9 & 4265.8 \\
NPSBZn & 2524.5 & 1987.95890 .2 & 5892.3 & 6536.3 & 3960.6 \\
NPSBZn + K & 2538.0 & 1991.25797 .8 & 5827.1 & 6809.7 & 4258.8 \\
\hline CV (\%) & 11.55 & 8.18 & 10.50 & 12.50 & 14.50 & 12.47 \\
LSD (0.05) & ns & ns & $n s$ & $n s$ & $n s$ & $n s$ \\
\hline
\end{tabular}

\section{- Bread wheat}

Grain yield of bread also showed the same trend as grain yield of food barley at Moretena jiru and Mojana wedera districts. As shown in Table 5 and 6, the highest grain were obtained from application of NPSBZn, however there was no significant difference among other treatments. From this finding, application of potassium did not bring better yield improvement.

Table 5: Mean response of bread wheat grain yield for application of Potassium fertilizer under balanced fertilization at Moretena jiru District, 201718

\begin{tabular}{l|cccccc}
\hline Treatment & Mangudo Burtilk Gerba & Bolo & Weyramba Mean \\
\hline NPS & 4232.2 & 4047.23802 .8 & 4441.9 & 5159.6 & 4336.8 \\
NPS+ K & 4332.0 & 4090.24001 .3 & 4669.1 & 5249.8 & 4468.5 \\
NPSBZn & 4400.7 & 4240.53972 .8 & 4761.0 & 5049.5 & 4484.9 \\
NPSBZn + K & 4207.1 & 4405.13881 .5 & 4824.4 & 5228.0 & 4509.2 \\
\hline CV (\%) & 9.65 & 7.05 & 8.06 & 13.14 & 12.64 & 10.92 \\
LSD (0.05) & ns & ns & $n s$ & $n s$ & ns & ns \\
\hline
\end{tabular}


Table 6: Mean response of bread wheat grain yield for application of Potassium fertilizer under balanced fertilization at Mojana wedera District, 201718

\begin{tabular}{l|cccccc}
\hline Treatment & \multicolumn{7}{|c}{ Begoch gat FilagenetFeres } & megalebiya & Birka & Sasit & Mean \\
\hline NPS & 2069.4 & 1925.9 & 3069.4 & 3604.2 & 3995.4 & 2932.9 \\
NPS+ K & 1930.6 & 2282.4 & 3333.3 & 3468.8 & 3333.3 & 2869.7 \\
NPSBZn & 2402.8 & 2291.7 & 3517.4 & 3531.3 & 4004.6 & 3149.5 \\
NPSBZn + K & 2120.4 & 1898.1 & 3506.9 & 3680.6 & 3546.3 & 2950.5 \\
\hline CV (\%) & 19.62 & 12.91 & 14.25 & 6.17 & 11.44 & 12.53 \\
LSD (0.05) & $n s$ & $n s$ & $n s$ & $n s$ & $n s$ & $n s$ \\
\hline
\end{tabular}

\section{Conclusion And Recommendation}

Generally applications of potassium in the form of $\mathrm{KCl}$ did not significantly impact the yield of sorghum, food barley and wheat at each district. Moreover, on the soil analysis result exchangeable $\mathrm{K}$ was within the range of medium, high and a very high category for crop production is not a limiting nutrient. However, the organic, phosphorus content of test sites was very low so that management of soil organic matter and application of adequate amount of nitrogen and phosphorus containing external fertilizer sources application is indispensable.

To confirm this result further investigation of the need of potassium fertilizer for major cereal crops and with different soil types and agro ecology is indispensable. This result showed that investment of potassium fertilizer is not agronomical feasible as additional to the site specific $\mathrm{N}$ and $\mathrm{P}_{2} \mathrm{O}_{5}$ recommended fertilizer. Finally, use of NPSBZn for sorghum and bread wheat and sole NPS for food barley with adjustment of $\mathrm{N}$ and $\mathrm{P}$ to site and crop specific could be advantageous without further investment of potassium at each district of the study sites.

\section{Acknowledgements}

Research was supported financially by Agricultural Growth Program II (AGP II) and many thanks to Debre Birhan Agricultural Research Center, Amhara Agricultural Research Institute, staff of Debre Birhan Soil and Water Management Directorate for better accomplishment of this experiment.

\section{References}

Abiye, A., M. Tekalign, D. Peden, and M. Diedhiou. (2004). Participatory On-Farm Conservation Tillage Trial in Ethiopian Highland Vertisols: The Impact of Potassium Application on Crop Yield. Expl. Agric. 40:369-379.

Agri-News. 2012. E-Newsletter: Wheat nutrition and fertilizer requirements: potassium. Available from:http: www1. agric.gov.ab.ca \$Department deptdocs.nsf All webdoc7998. 
ATA (Agricultural Transformation Agency) 2016. Ministry of Agriculture and Natural resources and Ethiopian Agricultural Transformation Agency.Addis Abeba, Ethiopia.

Gelderman, R. 2007. Fertilizer placement with seed - a decision aid. Proc. North Central ExtensionIndustry Soil Fertility Conference. Vol 23. Des Moines, lowa, US.

Jackson, M.L. 1958. Soil chemical analysis. Prentice Hall, Inc., Englewood Cliffs. N.J. Sixth Printing 1970. 498pp.

Merino-Gergichevich Alberdi. C.,M., vanov. A. G. I and Reye M. 2010. $\mathrm{Al}^{3+} \mathrm{Ca}^{2+}$ Interaction in Plants Growing in Acid Soils: Al-phytotoxicity response to calcareous amendments, Journal of Soil Science and Plant Nutrition, vol. 10, no. 3, pp. 217-243.

Olsen, S.R., Cole, V., Watanabe, F.S. and Dean, L.A. 1954. Estimations of available phosphorus in soils by extractions with sodium bicarbonate. U.S. Dept. Of Agric. Cric.939, USDA, Washington, DC

Pettigrew, W.T. (2008). Potassium influences on yield and quality production for maize, wheat, soybean and cotton. Physiolgia Plantarum, 133: 670-681.

SAS. 2002. SAS Version 9.0. SAS Institute Inc, Cary, NC.

Tekakign Mamo, I. Haque and E.A. Aduayi. 1991. Soil, plant, water, fertilizer, animal manure and compost analysis manual. Plant science division working document 13, ILCA, Addis Ababa, Ethiopia.

USDA (United States Department of Agriculture). Soil Mechanics Level IModule 3: USDA Textural Classification Study Guide. National Employee Development Staff, Soil Conservation Service, USDA; 1987

Walkley, A.J. and Black, I.A. 1934. An examination of the degtjareff method for determining soil organic matter and a proposed modification of the chromic acid titration method. Soil Science, 37: 29-38.

Zinabu W. 2016.A Review on Evaluation of Soil Potassium Status and Crop Response to Potassium Fertilization Journal of Environment and Earth Science. Vol.6, No.8, 2224-3216

\section{Figures}




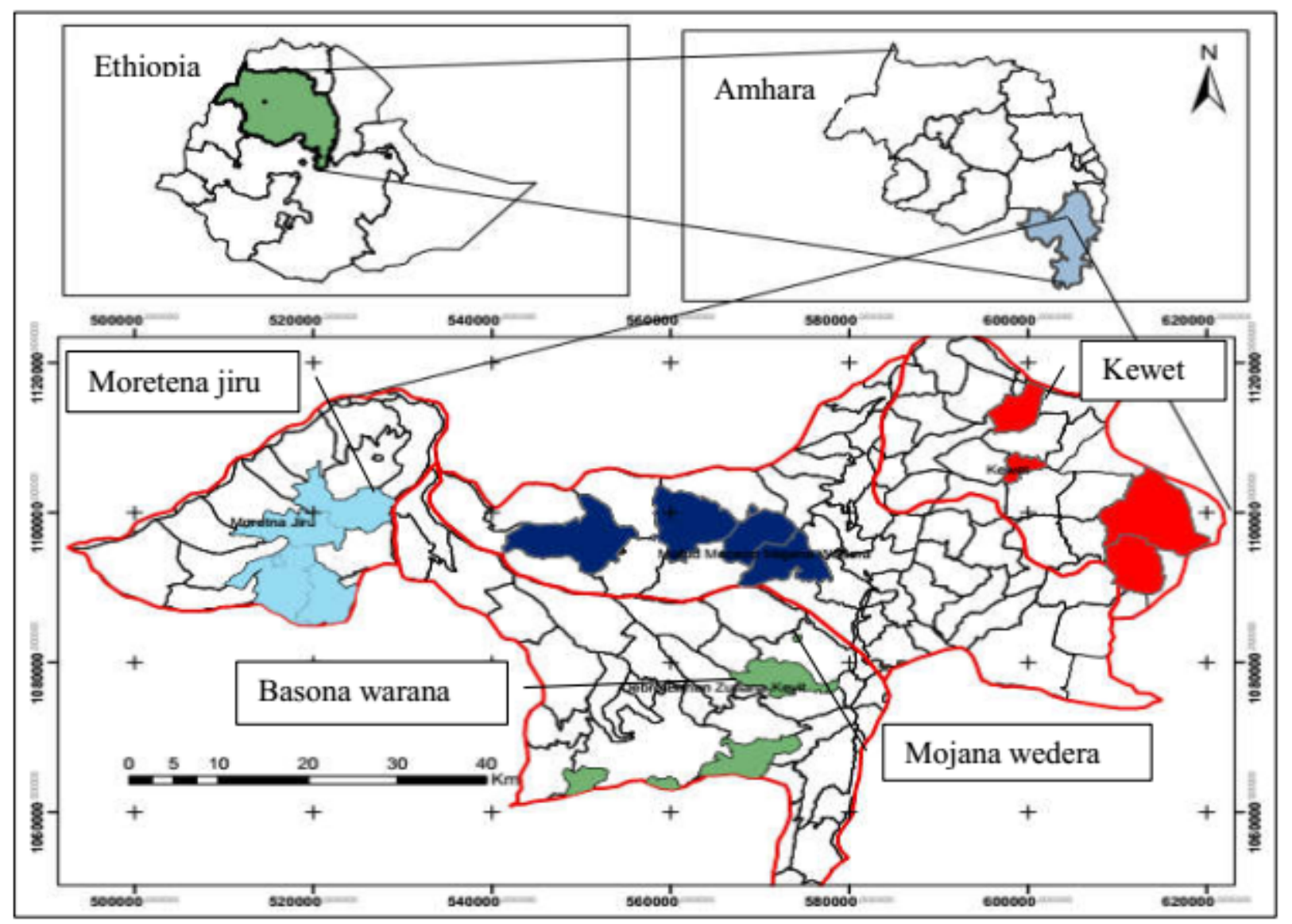

Figure 1

Map of the study area 


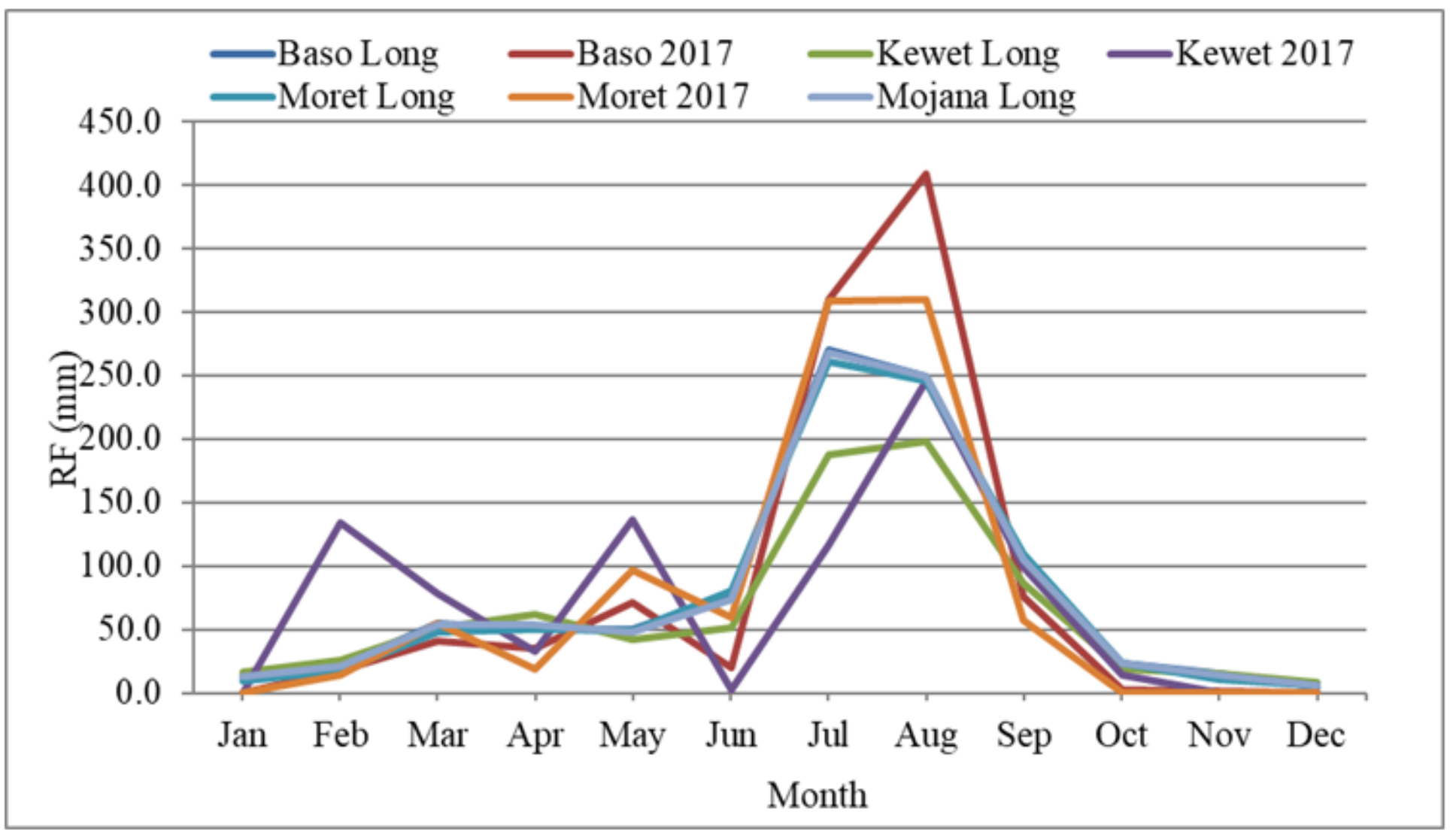

Figure 2

Long term and 2017 mean monthly rainfall distribution of the study area. 